FACTA UNIVERSITATIS

Series: Economics and Organization Vol. 16, N ${ }^{\mathrm{o}} 2,2019$, pp. $161-169$

https://doi.org/10.22190/FUEO1902161M

Original Scientific Paper

\title{
ANALYSIS OF VARIATIONS IN PROFITABILITY AND INDEBTEDNESS OF AGRICULTURAL COMPANIES IN AP VOJVODINA
}

UDC 334.7:63(497.11)

\section{Vera Mirović, Branimir Kalaš, Kristina Mijić}

University of Novi Sad, Faculty of Economics in Subotica, Serbia

\begin{abstract}
The measurement of agricultural companies in terms of profitability and indebtedness enables a real determination of the role and position of these companies in the agricultural sector in AP Vojvodina. The aim of the paper is to show the presence or absence of significant difference in the performance level of agricultural companies from the aspect of profitability and indebtedness. Agricultural companies in AP Vojvodina were more profitable and more indebted in the period before 2013 compared to the period after 2013. The results show that there is a significant difference in profitability level of agricultural companies in AP Vojvodina between the period before 2013 and after 2013. Using the MANOVA test, significant values for return on assets (ROA), return on equity (ROE) and net income per employee have been identified. On the other hand, results reflect there is no significant difference in the indebtedness level of agricultural companies in AP Vojvodina between the period before 2013 and after 2013.
\end{abstract}

Key words: agricultural companies, performance, profitability, indebtedness, MANOVA

JEL Classification: C13, Q14

\section{INTRODUCTION - THEORETICAL BACKGROUND}

Agriculture can be qualified as a specific sector which represents an essential segment in implementing the strategic vision of the Serbian economic development (PetrovićRanđelović et al. 2010). Agriculture in the Republic of Serbia has economic, social and political relevance and has a significant share in making the gross domestic product (Daku et al. 2005). It employs a large number of people (Kuzman et al. 2017).

Received January 23, 2019 / Accepted March 05, 2019

Corresponding author: Branimir Kalaš

University of Novi Sad, Faculty of Economics in Subotica, Segedinski put 9-11, 24000 Subotica, Serbia

E-mail: branimir.kalas@ef.uns.ac.rs 
The field of agriculture and the continuity and stability of agricultural production have an immeasurable relevance on the development of the entire economy (Pjanić et al. 2018). Mijić et al. (2016) emphasize the agro-economy sector as the bearer of economic development in Serbia. The specificity of business in the agricultural sector is reflected in the seasonal character of activity, the slow capital turnover and high production costs (Jakšić et al. 2011).

Due to the natural prerequisites for growth and development of agricultural production, agricultural companies in AP Vojvodina, besides satisfying domestic needs, also carry out business activity through the export of their products. The market conditions, economic crisis, the relatively low consumer power of population impose a constant need for analysis and improvement of business performance of agricultural companies in order to ensure their survival and development on the market (Kalaš et al. 2017). The importance of the agricultural sector in AP Vojvodina is manifested in the fact that this region includes $35 \%$ of the agricultural area of the Republic of Serbia (Andrašić et al. 2018).

Successful economic business, as well as permanent profit creation, is a requirement of long-term sustainability of agricultural companies (Jakšić et al. 2016). Profitability shows the earning power and business success of a company (Kimmel et al. 2012). Asiri (2015) and Vučković (2016) determined ROA and ROE as the most important factors of profitability. Jakšić et al. (2016) analyzed the profitability of milk production companies and milk processing companies in Serbia for the 2010-2013 period. Using the MANOVA test, they identified that there are no significant changes in the level of profitability during the observed period. On the other hand, indebtedness can have a positive or negative effect on company success in terms of profitability. Namely, company indebtedness indicates the structure of property resources and their safety from the aspect of financial (in)dependence (Mirović et al. 2018). It means that a higher share of own resources makes a wider space and greater financial dependence. However, indebtedness at an optimum level can have a positive influence on company performance. Companies need to balance the ratio of profitability and indebtedness and establish an effective nexus between these indicators. In the case of greater indebtedness, Račić et al. (2011) noticed that companies are forced to decrease financial leverage that causes a considerable fall in profitability.

The subject of research is the performance of agricultural companies in AP Vojvodina from 2006 to 2015. The paper includes four segments. The first segment shows theoretical background and similar research about variance analysis of key performance such as profitability, liquidity and indebtedness. After that, there is a trend analysis of the observed indicators of profitability and indebtedness in the ten year period which enables identification of their mean values and standard deviations. The fourth segment of the paper focuses on the multivariate analysis of variance with the aim to determine a potential significance in the profitability and indebtedness level of agricultural companies.

\section{DESCRIPTIVE ANALYSIS OF PROFITABILITY AND INDEBTEDNESS}

This segment of the paper reflects the trend of profitability indicators such as return on assets, return on equity, revenue per employee and net income per employee as well as liabilities capital ratio and interest coverage coefficient for the ten year period 2006-2015. 


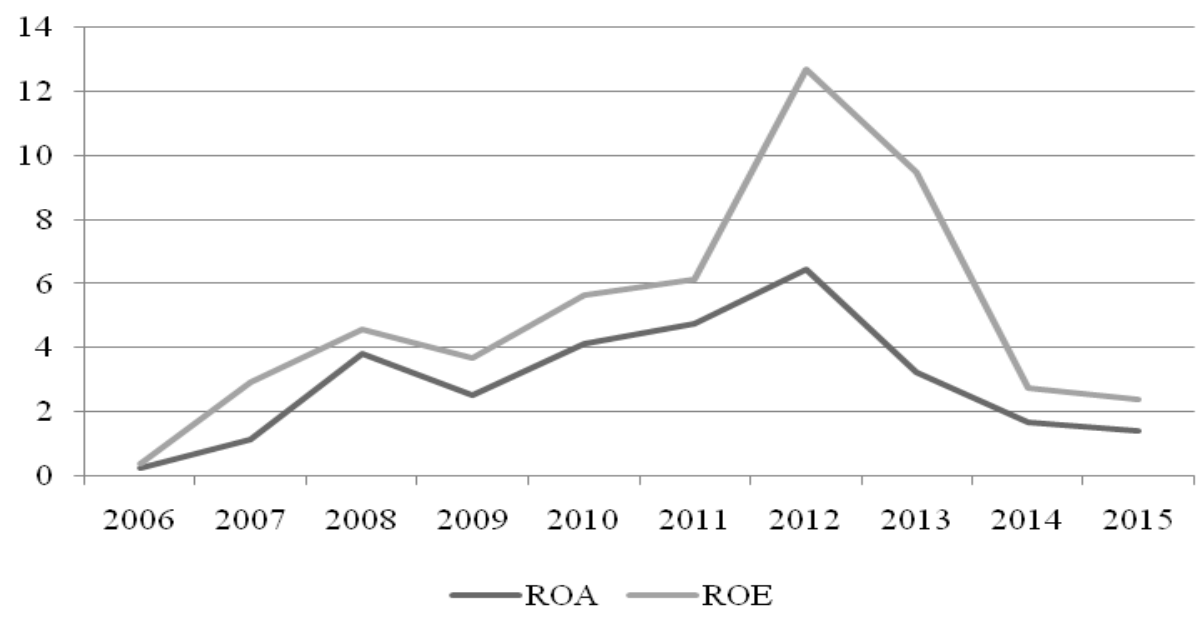

Fig. 1 Profitability of agricultural companies in AP Vojvodina Source: Author's calculation

Based on Figure 1, the analysis of return on assets (ROA) and return on equity (ROE) shows an increase from 2006 to 2012 while the observed indicators decreased after that period. Agricultural companies recorded the highest value of ROA (6.47\%) and ROE $(12.7 \%)$ in 2012 , while the lowest level of profitability was in 2006 when their values were under $0.5 \%$.

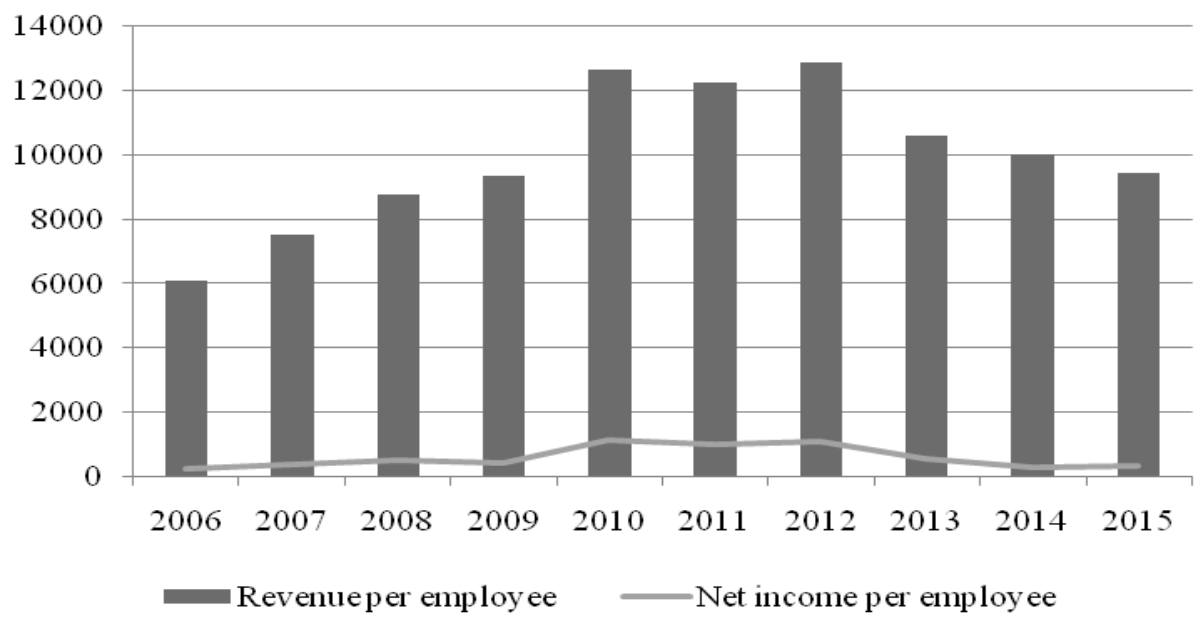

Fig. 2 Revenue and net income per employee of agricultural companies in AP Vojvodina Source: Author's calculation

Figure 2 shows the value of revenue and net income per employee of agricultural companies in AP Vojvodina from 2006 to 2015. 
There is an increased tendency of revenue per employee and net income per employee from 2006 to 2013 and after that, this indicator declined to the end of the observed period. The highest values of these indicators were recorded in 2013 (revenue per employee) and 2010 (net income per employee). On the other hand, the minimum values of revenue per employee and net income per employee were recorded at the beginning of the analyzed period.

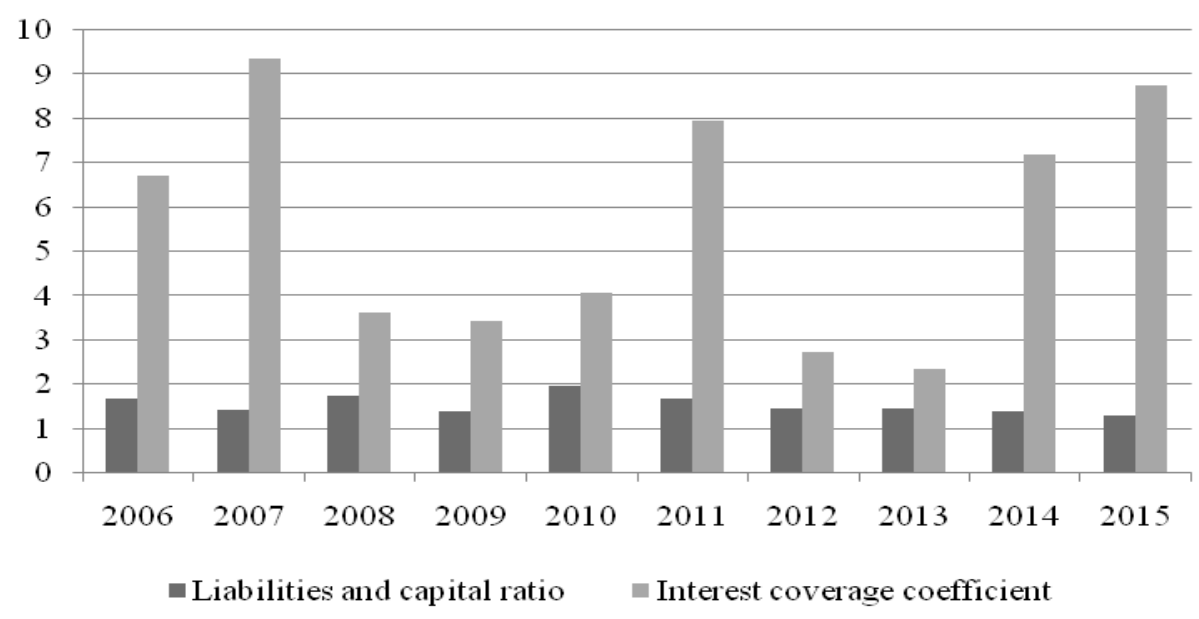

Fig. 3 Indebtedness of agricultural companies in AP Vojvodina Source: Author's calculation

After profitability analysis of agricultural companies in AP Vojvodina, Figure 3 shows their indebtedness from the aspect of liabilities and capital ratio and interest coverage coefficient. At the beginning of the analyzed period, indicators show increase until 2008, while their values were lower in 2009. After that, the maximum value of liabilities and capital ratio (1.98) was recorded, while in 2011 interest coverage coefficient had the greatest value of 7.97. Looking at the last three years, the average values of these indicators were 1.39 and 6.1, where agricultural companies achieved less indebtedness in the last year compared to the previous year. It means the declined value of liabilities and capital ratio and increased value of interest coverage coefficient of these companies in the analyzed period.

\section{MethodOLOGY}

The aim of this paper is to find out a potentially significant difference in the profitability and indebtedness level of agricultural companies in AP Vojvodina. The authors used return on assets, return on equity, revenue per employee and net income per employee as main profitability indicators, as well as liabilities and capital ratio and interest coverage coefficient in terms of indebtedness. 
Table 1 Review of observed variables

\begin{tabular}{lccc}
\hline Variable & Notation & Calculation & Unit \\
\hline Return on assets & ROA & Net income/Total assets & $\%$ \\
Return on equity & ROE & Net income/Capital & $\%$ \\
Revenue per employee & IPE & Sales revenue/Number of employees & $\%$ \\
Net income per employee & NRPE & Net income/Number of employees & $\%$ \\
Liabilities and capital ratio & LCR & Total liabilities/Capital & $\%$ \\
Interest coverage coefficient & ICC & Operating income/Interest expense & $\%$ \\
\hline \multicolumn{2}{c}{ Source: Authors }
\end{tabular}

The analysis of variation in the performance of agricultural companies should indicate if there are significant fluctuations in profitability and indebtedness level that the companies achieved in the observed period. Considering that more than one indicator describe profitability and indebtedness and to investigate the difference over the period, research includes a multivariate analysis of variance or variance analysis with more factors.

\section{RESULTS}

This segment provides descriptive information for the observed variables, as well as a multivariate analysis of variance in order to identify a potentially significant difference in profitability and indebtedness level of agricultural companies.

Table 2 Descriptive statistics of profitability

\begin{tabular}{lcrc}
\hline Variable & Period & Mean value & Standard deviation \\
\hline \multirow{2}{*}{ ROA } & Before 2013 & 0,052 & 0,120 \\
& After 2013 & 0,026 & 0,064 \\
& Total & 0,039 & 0,097 \\
\hline \multirow{2}{*}{ ROE } & Before 2013 & 0,110 & 0,138 \\
& After 2013 & 0,062 & 0,071 \\
& Total & 0,086 & 0,113 \\
\hline \multirow{2}{*}{ Revenue per } & Before 2013 & $12.646,050$ & $21.972,565$ \\
employee & After 2013 & $10.220,640$ & $9.155,874$ \\
& Total & $11.452,90$ & $16.937,281$ \\
\hline \multirow{2}{*}{ Net income per } & Before 2013 & $1.076,84$ & $2.741,611$ \\
employee & After 2013 & 445,62 & $1.357,285$ \\
& Total & 766.32 & 2.192 .330 \\
\hline
\end{tabular}

Source: Author's calculation

The results of profitability in the period before and after 2013 indicate that agricultural companies achieved better performance before 2013. For example, the average ROA was $5.2 \%$ in the first period while in the period after 2013 it was $2.6 \%$. Similarly, agricultural companies reached a higher level of ROE before 2013, when it was $11 \%$, while after 2013, the value of this indicator declined to $6.2 \%$. Mean values of ROA and ROE are $3.9 \%$ and $8.6 \%$ where the standard deviation is higher at the second indicator which implies a greater 
difference between the minimum and the maximum value of ROE. Further, revenue and net income per employee was higher before 2013, whereas these variables decreased in the next period by 2,425,410 RSD and 631,22 RSD.

Table 3 Multivariate analysis results - profitability

\begin{tabular}{llccccc}
\hline & Effect & Value & F & Hypothesis df & Error df & Sig. \\
\hline \multirow{5}{*}{ Period } & Pillai's Trace & 0.057 & 3.659 & 4.000 & 243.000 & 0.006 \\
& Wilks' Lambda & 0.943 & 3.659 & 4.000 & 243.000 & 0.006 \\
& Hotelling's Trace & 0.060 & 3.659 & 4.000 & 243.000 & 0.006 \\
& Roy's Largest Root & 0.060 & 3.659 & 4.000 & 243.000 & 0.006 \\
\hline
\end{tabular}

Source: Author's calculation

Considering that obtained value of Pillai's Trace 0.006 is lower than 0.05 , it can be concluded that there is a significant difference in the profitability level of agricultural companies in AP Vojvodina between the periods before and after 2013.

Table 4 Test of between-subject effects for profitability

\begin{tabular}{llccrc}
\hline Source & Profitability & Type III Sum of Squares & df & \multicolumn{1}{c}{ F } & \multicolumn{1}{c}{ Sig. } \\
\hline \multirow{5}{*}{ Period } & ROA & 0.043 & 1 & 4.522 & 0.034 \\
& ROE & 0.144 & 1 & 11.677 & 0.001 \\
& Revenue per employee & $364,627,045.838$ & 1 & 1.272 & 0.260 \\
& Net income per employee & $24,696,670.321$ & 1 & 5.226 & 0.023 \\
\hline
\end{tabular}

Source: Author's calculation

The obtained significance results for ROA, ROE and net income per employee are less than 0.05 which means that there is a significant difference in these indicators realized by agricultural companies in AP Vojvodina in the period before and after 2013. On the other hand, variations of income per employee are not significant in the analyzed period. As a cause of the resulting changes in the profitability level, it can also be requested in external factors or changes in the legal regulations and criteria for the classification of companies by size starting from 2013. This significantly influenced the change in company size and transition of a certain number of companies from the category of large to medium-sized companies as well as medium-sized to small companies. The decrease in the number of large and medium-sized companies also involves spilling activity and success of this companies group into a group of micro and small agricultural companies.

Table 5 Descriptive statistics of indebtedness

\begin{tabular}{lccc}
\hline Variable & Period & Mean value & Standard deviation \\
\hline \multirow{2}{*}{ Liabilities and } & Before 2013 & 1.83 & 2.899 \\
capital ratio & After 2013 & 1.45 & 2.012 \\
& Total & 1.64 & 2.502 \\
\hline \multirow{2}{*}{ Interest coverage } & Before 2013 & 5.360 & 26.278 \\
coefficient & After 2013 & 9.498 & 42.059 \\
& Total & 7.404 & 34.965 \\
\hline
\end{tabular}

Source: Author's calculation 
The results of indebtedness in the period before and after 2013 show that agricultural companies had a higher value of liabilities and capital ratio before 2013 . The mean value of this indicator was 1.83 which is higher by 0.38 compared to the period after 2013 . On the other hand, average interest coverage coefficient was 9.498 after 2013 which is higher by 4.138 compared to the period before 2013. Standard deviation is higher at interest coverage coefficient which means there is a greater difference between the minimum and the maximum value of this indicator.

Table 6 Multivariate analysis results - indebtedness

\begin{tabular}{llccccc}
\hline & Effect & Value & F & Hypothesis df & Error df & Sig. \\
\hline \multirow{5}{*}{ Period } & Pillai's Trace & 0.008 & 1.013 & 2.000 & 246.000 & 0.365 \\
& Wilks' Lambda & 0.992 & 1.013 & 2.000 & 246.000 & 0.365 \\
& Hotelling's Trace & 0.008 & 1.013 & 2.000 & 246.000 & 0.365 \\
& Roy's Largest Root & 0.008 & 1.013 & 2.000 & 246.000 & 0.365 \\
\hline \multicolumn{7}{c}{ Source: Author's calculation }
\end{tabular}

Bearing in mind that obtained value of Pillai's Trace 0.365 is higher than 0.05 , it can be noticed that there is no significant difference in the indebtedness level of agricultural companies in AP Vojvodina between the periods before and after 2013.

Table 7 Test of between-subject effects for indebtedness

\begin{tabular}{llcccc}
\hline Source & Debt & $\begin{array}{c}\text { Type III Sum } \\
\text { of Squares }\end{array}$ & Df & F & Sig. \\
\hline \multirow{2}{*}{ Period } & Liabilities and capital ratio & 8.681 & 1 & 1.390 & 0.240 \\
& Interest coverage coefficient & $1,065.991$ & 1 & 0.871 & 0.351 \\
\hline
\end{tabular}

Source: Author's calculation

The results in Table 7 show that significance level of liabilities and capital ratio and interest coverage coefficient is above 0.05 which implies that there are no significant differences in the indebtedness level of agricultural companies in AP Vojvodina in the period before and after 2013.

\section{CONCLUSION}

In order to test the stability in the level of agricultural companies' performance in AP Vojvodina, the paper has tested potential significant variations in the level of profitability and indebtedness of these companies. Research results show that agricultural companies were more profitable and more indebted in the period before 2013 compared to the period after 2013. Furthermore, it has been determined that there is a significant difference in profitability level of agricultural companies in AP Vojvodina between the period 2013 and after 2013. Precisely, the obtained significance results are identified for ROA, ROE and net income per employee, which values were less than 0.05 which implies that there is a significant difference in these indicators realized by agricultural companies in AP Vojvodina in the analyzed period. Since 2013, there has been a change in the classification 
of companies by size which implies a decrease in the number of medium-sized and large companies and increase in the number of micro and small companies. According to this, part of income and result that were achieved by medium-sized and large agricultural companies by 2013 has spilt into income and result of micro and small companies since 2013. On the other hand, the results of the MANOVA show that there is no significant difference in indebtedness of agricultural companies in AP Vojvodina between the period before 2013 and after 2013.

Acknowledgement: The paper is a result of work on the project "Sustainability and improvement of agricultural companies performance in AP Vojvodina" - short-term project of special interest for sustainable development in AP Vojvodina in 2017.

\section{REFERENCES}

Andrašić, J., Mijić, K., Mirović, V. \& Kalaš, B. (2018). The modelling factors of agricultural companies performances. Custose@gronegocio on line, 14 (4), 223-240.

Asiri, B. (2015). How investors perceive financial ratios at different growth opportunities and financial leverages. Journal of Business Studies Quarterly, 6 (3), 1-12.

Daku, L., Norton, G., Taylor, D. \& Qenani-Petrela, E. (2005). Agricultural extension in South-Eastern Europe: Issues of transition and sustainability. The Journal of Agricultural Education and Extension, 11 (1-4), 49-61.

Jakšić, D., Vuković, B. \& Mijić, K. (2011). Analysis of the financial position of agricultural companies in the Republic of Serbia. Economics of Agriculture, 58 (1), 81-90.

Jakšić, D., Mijić, K., Zekić, S. \& Poljašević, J. (2015). Comparative profitability analysis of milk production to milk processing companies in Serbia.Custose@gronegocio on line, 11 (3), 206-226.

Jakšić, D., Ristić, M., Mijić, K. \& Zekić, S. (2016). Profitabilnost poljoprivrednih preduzeća u zemljama Jugoistočne Evrope [Profitability of agricultural enterprises in the countries of Southeast Europe]. Agroekonomika, 45 (71), 1-11.

Kalaš, B. Mijić, K. \& Andrašić, J. (2017). Performanse poljoprivrednih preduzeća u AP Vojvodini [The performance of agricultural companies in Vojvodina]. Agroekonomika, 46 (75), 43-52.

Kimmel, P., Weygandt, J. \& Kieso, D. (2012). Financial Accounting. New Jersey: John Wiley \& Sons.

Kuzman, B., Đurić, K., Mitrović, Lj. \& Prodanović, R. (2017). Agricultural budget and agriculture development in Republic of Serbia. Economics of Agriculture, 64 (2), 515-531.

Mijić, K., Zekić, S. \& Jakšić, D. (2016). Profitability analysis of meat industry in Serbia. Facta Universitatis Series: Economics and Organizations, 13 (4). 379-386.

Mirović, V., Mijić, K. \& Andrašić, J. (2018). Korporativne performanse poljoprivrednih preduzeća u AP Vojvodini sa aspekta izvora finansiranja [Corporate performance of agricultural enterprises in AP Vojvodina from the aspect of financing sources]. Anali Ekonomskog fakulteta u Subotici, 54 (40), 95-105.

Petrović-Ranđelović, M. \& Marjanović, V. (2010). The main trends and prospects of the agricultural development in Serbia. Facta Universitatis Series: Economics and Organization, 7 (4), 373-384.

Pjanić, M., Vuković, B. \& Mijić, K. (2018). Analysis of the Market Concentration of Agricultural Enterprises in AP Vojvodina. Strategic Management, 23 (4), 40-45.

Račić, Ž., Barjaktarović, L. \& Zeremski, A. (2011). Analysis of indebtedness impact on the profitability of successful domestic companies in the financial crisis. Industry, 39 (3), 45-60.

Vučković, B. (2016). Causes of different profitability of agricultural sector. Economics of Agriculture, 63 (1), 123-141. 


\section{ANALIZA VARIJACIJA U PROFITABILNOSTI I ZADUŽENOSTI POLJOPRIVREDNIH PREDUZEĆA U AP VOJVODINI}

Merenje poljoprivrednih preduzeća u smislu profitabilnosti $i$ zaduženosti omogućava realno utvrđivanje uloge i pozicije ovih preduzeća u poljoprivrednom sektoru AP Vojvodine. Cilj ovog rada je da prikaže prisustvo ili odsustvo značajne razlike u nivou performansi poljoprivrednih preduzeća sa aspekta profitabilnosti i zaduženosti. Poljoprivredna preduzeća u AP Vojvodini bila su profitabilnija i zaduženija u periodu pre 2013. godine u odnosu na period nakon 2013. godine. Rezultati pokazuju da postoji značajna razlika u nivou profitaibilnosti poljoprivrednih preduzeća u AP Vojvodini između perioda pre i posle 2013. godine. Koristeći MANOVA test, utvrđena je značajnost kod povrata na imovinu, povrata na kapitala i neto rezultata po zaposlenom. S druge strane, rezultati pokazuju da ne postoji značajna razlika u nivou zaduženosti poljoprivrednih preduzeća u AP Vojvodini između perioda pre i posle 2013. godine.

Ključne reči: poljoprivredna preduzeća, performanse, profitabilnost, zaduženost, MANOVA 